Article

\title{
Amorphous Nanosuspensions Aggregated from Paclitaxel-Hemoglobulin Complexes with Enhanced Cytotoxicity
}

\author{
Chao Qin ${ }^{\dagger}$, Xiaofei Xin ${ }^{\dagger}$, Xue Pei, Lifang Yin * and Wei He * \\ Department of Pharmaceutics, School of Pharmacy, China Pharmaceutical University, Nanjing 210009, China; \\ 1020142415@cpu.edu.cn (C.Q.); 15311010037@stu.cpu.edu.cn (X.X.); xuepeicpu@gmail.com (X.P.) \\ * Correspondence: 1019940752@cpu.edu.cn (L.Y.); weihe@cpu.edu.cn (W.H.) \\ † Chao Qin and Xiaofei Xin contributed equally to this work.
}

Received: 7 June 2018; Accepted: 4 July 2018; Published: 13 July 2018

\begin{abstract}
Amorphous nanosuspensions (ANSs) enable rapid release and improved delivery of a poorly water-soluble drug; however, their preparation is challenging. Here, using hemoglobin $(\mathrm{Hb})$ as a carrier, ANSs aggregated from paclitaxel (PTX)-Hb complexes were prepared to improve delivery of the hydrophobic anti-cancer agent. An affinity study demonstrated strong interaction between $\mathrm{Hb}$ and PTX. Importantly, the complexes could aggregate into $<300 \mathrm{~nm}$ ANSs with high drug loading, which acidic condition facilitated their formation. Furthermore, the ANSs possessed improved cytotoxicity against cancer cells over the crystalline nanosuspensions. Taken together, ANSs aggregated from PTX-Hb complexes were developed, which could kill cancer cells with high efficiency.
\end{abstract}

Keywords: nanosuspensions; amorphous; affinity; drug-protein complexes; cytotoxicity

\section{Introduction}

Over $40 \%$ of the marked products and approximately $90 \%$ of new drug candidates are poorly water-soluble compounds based on the biopharmaceutical classification system (BCS) [1]. Nanotechnology is one of the most commonly exploited approaches to enhancing the solubility and bioavailability of insoluble drugs [2,3]. Nanosuspensions of insoluble drugs, in which the drug can exist in crystalline or amorphous form, are a promising nanomedicine, possessing merits including extremely high drug-loading capacity, easy preparation, enhanced dissolution rate and saturation solubility, reproducibility, improved dose-bioavailability proportionality and increased patient compliance [4-6]. In contrast with crystalline nanosuspensions, amorphous nanosuspensions (ANSs) with unordered arrangement of molecules allow for faster dissolution rate and higher solubility [7-9].

Recently, it was reported that the nanocrystals were well uptaken by KB and HT-29 cells; however, it takes several hours to dissolve the intracellular crystals [10,11]. As is well known, the slowed drug release in cells could discount the treatment effect on cancer because keeping low drug concentration over time would induce multidrug resistance. In previous reports [12,13], using denatured soy protein isolate as a stabilizer, a nanosuspension formulation combining crystalline and amorphous drug was developed using a technique whereby the drug-protein complexes coated the nanocrystals of the insoluble drug. Inspired by these findings, we hypothesized that ANSs could be prepared via the aggregation of drug-protein complexes and were able to kill cancer cells with higher efficiency for rapid intracellular release post internalization. 
Hemoglobin $(\mathrm{Hb})$ - having four globular polypeptide subunits and a molecular weight of $64.5 \mathrm{kDa}$-is an abundant blood protein [14]. $\mathrm{Hb}$ can transport oxygen to the lung efficiently, as well as other organs, and is therefore regarded as an ideal oxygen carrier. On the other hand, paclitaxel (PTX) is one of the more frequently used anti-cancer drugs, acting through suppressing the microtubule dynamic instability and the resultant cell division [15]. Due to its extremely low water-solubility, a surfactant, Cremophor EL, has to be formulated into the marked product, Taxol, to enhance its solubility. However, the addition of Cremophor EL could induce allergenicity and toxicity to the body and thus limit PTX's clinical use [16]. Consequently, Cremophor EL-free formulation for PTX is desired. With the ability to bind with hydrophobic agent and high biocompatibility, herein, $\mathrm{Hb}$ was used as the carrier to prepare drug- $\mathrm{Hb}$ complexes and ANSs with improved delivery of PTX.

\section{Materials and Methods}

\subsection{Materials}

Human hemoglobin (H7379, Hb), $\beta$-lactoglobulin (L3908, $\beta$-LG), fluorescein isothiocyanate isomer I (F7250, FITC), 3-(4,5-dimethylthiazol-2-yl)-2,5-diphenyltetrazolium bromide (MTT) and sodium azide $\left(\mathrm{NaN}_{3}\right)$ were purchased from Sigma-Aldrich (St. Louis, MO, USA). Paclitaxel (PTX) was from Yew Biotechnology Co., Ltd. (Suzhou, China). Taxol was obtained from Bristol-Myers Squibb Investment Co., Ltd. (Shanghai, China). Lyso-tracker red, Annexin V-FITC/PI staining kit and 4',6-diamidino-2-phenylindole (DAPI) were purchased from Beyotime Biotechnology (Shanghai, China). Cytochalasin D (Cy-D), nystatin, chlorpromazine (CPZ), methyl- $\beta$-cyclodextrin (M-CD), nocodazole (NOD), monensin (MON) and deoxyglucose (DG) were obtained from Aladdin Biochemical Technology Co., Ltd. (Shanghai, China). Fetal bovine serum (FBS), RPMI 1640, and phosphate buffer saline (PBS) were purchased from Thermo Fisher Scientific, Inc. (Waltham, MA, USA).

\subsection{Preparation}

PTX-Hb complexes were prepared by an anti-solvent precipitation method described in a previous report [17]. Briefly, a certain amount of PTX and $10 \mathrm{mg}$ of $\mathrm{Hb}$ were dissolved in $1 \mathrm{~mL}$ of acetone and $10 \mathrm{~mL}$ of distilled water, respectively. Then PTX acetone solution was slowly added to the $\mathrm{Hb}$ solution with vigorous stirring in ice bath, followed by treatment in an ultrasonic probe $(20-25 \mathrm{kHz}$, Scientz Biotechnology Co., Ltd., Ningbo, China) at $350 \mathrm{~W}$ for $15 \mathrm{~min}$ and evaporation under reduced pressure conditions.

FITC-labelled complexes of ANSs (FITC-ANSs) were prepared using a similar process, except that FITC was conjugated with the protein prior to mixing with the organic phase.

Crystalline nanosuspensions of PTX, $\beta$-LG-coated PTX nanocrystals (LPNs), and FITC-labelled LPNs (FITC-LPNs) were prepared by an anti-solvent precipitation procedure described in a previous report [18].

\subsection{Characterization}

Hydrodynamic diameter, zeta potential and polydispersity index were determined using a 90Plus Particle Size Analyzer (Brookhaven Instruments, Holtsville, NY, USA). Before determination, the sample was diluted approximately 10-fold.

Scanning electron microscopy (SEM, Hitachi, Tokyo, Japan) was used to investigate the morphology of ANSs. After centrifugation at $100,000 \times \mathrm{g}$ for $10 \mathrm{~min}$ at $4{ }^{\circ} \mathrm{C}$ (Beckman Coulter Optima L-80XP, Brea, CA, USA), the precipitation was collected and diluted 100-fold. Then one drop of the sample was placed on the surface of a silicon chip, left overnight to evaporate the water at $25^{\circ} \mathrm{C}$, followed by coating with gold under vacuum condition and SEM examination at an excitation voltage of $10 \mathrm{kV}$. 


\subsection{Fluorescence Spectra}

The fluorescence spectra were recorded with a fluorescence spectrometer (SHIMADZU RF-5301PC, Kyoto, Japan) with an emission spectrum of 300-500 nm and excitation wavelength of $295 \mathrm{~nm}$. The resolutions of the emission and excitation were $5 \mathrm{~nm}$ and $15 \mathrm{~nm}$, respectively. The protein concentration in $\mathrm{pH} 7 \mathrm{PBS}$ was $1 \mathrm{mg} / \mathrm{mL}$.

\subsection{Circular Dichroism (CD) Spectra}

CD spectra were recorded in a J-810 spectrometer (Tokyo, Japan) with a temperature-controlling unit and a quartz cuvette. The ellipticity was expressed in millidegrees. The analysis conditions were as follows: Bandwidth, $1 \mathrm{~nm}$; response, $1 \mathrm{~s}$; wavelength range, 250-190 nm; scan rate, $100 \mathrm{~nm} / \mathrm{min}$; cell length, $0.1 \mathrm{~cm}$; temperature, $25{ }^{\circ} \mathrm{C}$; protein concentration, $1 \mathrm{mg} / \mathrm{mL}(\mathrm{pH} 7.0)$.

\subsection{Affinity Study}

The affinity of drug-protein was determined via the parameters including fluorescence quenching rate constant $\left(K_{\mathrm{q}}\right)$, number of binding site $(n)$, and binding constant $\left(K_{\mathrm{a}}\right)$.

\subsection{Powder X-Ray Diffraction (PXRD) and Differential Scanning Calorimetry (DSC)}

PXRD was performed in an X'Pert PRO diffractometer (Panalytical, Holland) under the following conditions: $2 \theta$ range, $3-50^{\circ}$; san rate, $1^{\circ} / \mathrm{min}$; step size, $0.02^{\circ}$; step time, $1 \mathrm{~s}$. The patterns were collected at $40 \mathrm{kV}$ and $60 \mathrm{~mA}$ with $\mathrm{Cu} \mathrm{K} \alpha$ radiation $(\lambda=0.154 \mathrm{~nm})$.

DSC analysis was conducted on a TA-Q2000 differential scanning calorimeter (TA Instruments, New Castle, DE, USA). A fixed weight ( $5 \mathrm{mg}$ ) of sample was placed in an aluminum pan and sealed. The samples were heated from 30 to $300^{\circ} \mathrm{C}$ at a heating rate of $10 \mathrm{~K} / \mathrm{min}$. The instrument was calibrated with indium. All DSC analyses were performed in nitrogen atmosphere at a flow rate of $100 \mathrm{~mL} / \mathrm{min}$.

\subsection{In Vitro Release}

The drug release in vitro was investigated using a dialysis method. ANSs with $5 \mathrm{mg}$ PTX and Taxol were transferred into a dialysis bag (molecular weight cut-off, $3500 \mathrm{Da}$ ) and dialyzed with continuous shaking at $120 \mathrm{rpm}$ in pH 7.4 PBS containing $1 \%$ Tween $80(w / v)$ at $37^{\circ} \mathrm{C}$. At specific time points, $1 \mathrm{~mL}$ of the dialysis solution was sampled and replaced with $1 \mathrm{~mL}$ fresh medium. The samples were then qualified by a high performance liquid chromatography (HPLC) system (SHIMAZU LC-10AT, Tokyo, Japan) according to a previous report [17].

\subsection{Flow Cytometry (FCM)}

For quantification of cellular uptake, FITC-labelled nanoparticles were incubated with A549 cells at $2.5 \mu \mathrm{g} / \mathrm{mL}$ of FITC at $37^{\circ} \mathrm{C}$ or $4{ }^{\circ} \mathrm{C}$. A fixed time later, the cells were washed three times, trypsinized and determined by FCM (BD FACSCalibur, Franklin Lakes, NJ, USA).

To investigate the endocytosis mechanism, A549 cells were pretreated with different uptake inhibitors at $37{ }^{\circ} \mathrm{C}$ for $30 \mathrm{~min}$ before incubation with ANSs. The inhibitors included Cy-D $(10 \mu \mathrm{g} / \mathrm{mL})$, nystatin $(10 \mu \mathrm{M}), \mathrm{CPZ}(10 \mu \mathrm{g} / \mathrm{mL}), \mathrm{M}-\mathrm{CD}(2.5 \mathrm{nM}), \mathrm{NOD}(20 \mu \mathrm{M}), \mathrm{MON}(200 \mathrm{nM})$, $\mathrm{NaN}_{3}(10 \mathrm{nM})+\mathrm{DG}(50 \mathrm{nM})$.

An apoptosis test in A549 cells was performed using Annexin V-FITC/PI staining kits and FCM. The cells were treated with different formulations with a fixed PTX concentration of $10 \mu \mathrm{g} / \mathrm{mL}$ for $48 \mathrm{~h}$ at $37^{\circ} \mathrm{C}$. Then the cells were trypsinized, harvested, stained with the kits according to the manufacturer's protocol, and analyzed by FCM.

\subsection{Confocal Imaging}

A549 cells $\left(1 \times 10^{5}\right)$ were seeded in confocal dishes and allowed to adhere for $24 \mathrm{~h}$. FITC-labelled nanoparticles were incubated with A549 cells at $2.5 \mu \mathrm{g} / \mathrm{mL}$ of FITC at $37^{\circ} \mathrm{C}$ for $4 \mathrm{~h}$. Then the cells were 
washed three times with PBS and incubated with lyso-tracker-red for $2 \mathrm{~h}$ at $37^{\circ} \mathrm{C}$. Finally, the cells were rinsed three times again with PBS and observed using a confocal laser scanning microscope (CLSM, LSM700, Carl Zeiss, Oberkochen, Germany).

\subsection{Cytotoxicity}

4T1 and A549 cell viabilities against nanoparticles were determined by MTT assay. Cells $\left(1 \times 10^{5}\right)$ and nanoparticles were added to each well, followed by incubation for $48 \mathrm{~h}$ at $37^{\circ} \mathrm{C}$. Then the treated cells were incubated with RPMI 1640 media containing $20 \mu \mathrm{L}$ of MTT $(5 \mathrm{mg} / \mathrm{mL})$ for $4 \mathrm{~h}$. Following removal of the media, DMSO was added to dissolve the violet crystals for absorbance measurement at $570 \mathrm{~nm}$ using a microplate reader (Multiskan, FC, Woburn, MA, USA).

\subsection{Statistical Analysis}

One-way analysis of variance was performed to assess the statistical significance of the differences between samples. The results are expressed as the means \pm standard deviation. Significant differences were set as $p<0.05$.

\section{Results and Discussion}

\subsection{Drug-Protein Complex}

Local information regarding conformational changes in a protein resulting from its interaction with other agents can be detected using intrinsic fluorescence spectra. The maximal fluorescence at the excitation wavelength of approximately $340 \mathrm{~nm}$ is predominantly generated by the Trp residues surrounded by the hydrophobic residues of proteins. The fluorescence emission spectra of ANSs with different drug loading are shown in Figure 1. At PTX loading less than $1 \mathrm{mg}$, the maximum fluorescence intensity at $340 \mathrm{~nm}$ decreased significantly for drug incorporation (Figure 1A); by contrast, the maximum fluorescence increased with an increase in drug loading from 5 to $50 \mathrm{mg}$ (Figure 1B). The fluorescence quenching at low drug loading suggested the formation of a protein-drug complex [19,20]. The increased fluorescence at high drug loading indicated the Trp residues were surrounded in a more hydrophobic environment and, consequently, demonstrated the aggregation of protein-drug complex [12].

A



B

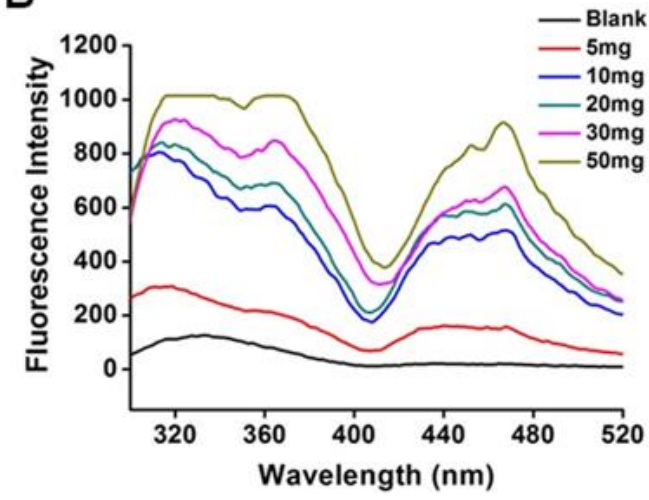

Figure 1. The fluorescence emission spectrum of amorphous nanosuspensions (ANSs) with paclitaxel (PTX) from 0-1 mg (A) and from 5-50 mg (B).

To further quantify the affinity between the drug and protein, the quenching rate constant $\left(K_{\mathrm{sv}}\right)$ and fluorescence quenching rate constant $\left(K_{\mathrm{q}}\right)$ were calculated by the Stern-Volmer formula [21]:

$$
F_{0} / F=1+K_{\mathrm{SV}}[Q]=1+K_{q} \tau_{0}[Q]
$$


where $F_{0}$ and $F$ are the steady-state fluorescence intensities in the absence and presence of quencher, respectively; $K_{\mathrm{sv}}$ is the Stern-Volmer quenching rate constant; $K_{\mathrm{q}}$ is the quenching rate constant of $\mathrm{Hb} ; \tau_{0}$ is the average lifetime of the protein without the quencher being equal to $10^{-8} \mathrm{~s}$; and [Q] is the concentration of quencher.

For the static quenching, the binding constant $\left(K_{\mathrm{a}}\right)$ and number of binding sites $(n)$ may be calculated as following equation:

$$
\log \left[\left(F_{0}-F\right) / F\right]=\log K_{\mathrm{a}}+n \log [Q]
$$

$K_{\mathrm{a}}$ and $n$ can be obtained by the intercept and slope of the double logarithm regression curve of $\log \left[\left(F_{0}-F\right) / F\right]$ versus $\log [Q]$, respectively.

As shown in Table 1, the values of $K_{\mathrm{q}}$ at three temperatures were markedly greater than the collisional quenching constant $\left(2 \times 10^{10} \mathrm{M}^{-1} \mathrm{~s}^{-1}\right)$ [22]. These results demonstrated that the fluorescence quenching of protein was induced by the binding changes rather than collisional quenching and thus indicated the formation of ground state complexes between protein and drug. The unchanged $K_{\mathrm{sv}}$ for temperature rising ascertained this result [23]. Accordingly, the value of $K_{\mathrm{a}}$ could be calculated by Equation (2). The $K_{\mathrm{a}}$ of the complexes was $1.6 \times 10^{6} \mathrm{~L} / \mathrm{mol}$ at $298 \mathrm{~K}$. Generally, a value of $K_{\mathrm{a}}$ greater than $1 \times 10^{4} \mathrm{~L} / \mathrm{mol}$ indicated a robust interaction between protein and drug [21]. Even at the higher temperature of $308 \mathrm{~K}$, the $K_{\mathrm{a}}$ was still greater than $1 \times 10^{4}$. Collectively, these results demonstrated strong interaction between the protein and the drug.

Table 1. The binding constant of hemoglobin $(\mathrm{Hb})$ and paclitaxel (PTX) in amorphous nanosuspensions (ANSs) analyzed by modified Stern-Volmer equation.

\begin{tabular}{ccccc}
\hline $\mathbf{T}(\mathbf{K})$ & $\mathbf{K}_{\mathbf{s v}} /\left(\mathbf{M}^{-\mathbf{1}}\right)$ & $\mathbf{K}_{\mathbf{q}} /\left(\mathbf{M}^{-\mathbf{1}} \cdot \mathbf{s}^{-\mathbf{1}}\right)$ & $\boldsymbol{n}$ & $\mathbf{K}_{\mathbf{a}} /\left(\mathbf{M}^{-\mathbf{1}}\right)$ \\
\hline 288 & $3.5 \times 10^{9}$ & $3.5 \times 10^{17}$ & 0.8 & $7.2 \times 10^{7}$ \\
298 & $2.7 \times 10^{9}$ & $2.7 \times 10^{17}$ & 0.7 & $1.6 \times 10^{6}$ \\
308 & $1.5 \times 10^{9}$ & $1.5 \times 10^{17}$ & 0.5 & $1.7 \times 10^{4}$ \\
\hline
\end{tabular}

\subsection{Preparation and Characterization of ANSs}

ANSs were prepared by an anti-solvent precipitation method followed by ultrasonic treatment. First, the effect of drug loading from 5\% to $200 \%$ (compared to the weight of protein, $w / w$ ) on the particle size of ANSs was investigated (Figure 2A). All ANSs had a diameter of $<300 \mathrm{~nm}$; while $<200 \mathrm{~nm}$-ANSs were from the formulations with drug loadings of $30 \%$ and $50 \%$.

Second, the effect of $\mathrm{pH}$ on the particle size of ANSs with drug loading of $50 \%$ was investigated (Figure 2B). Interestingly, under acidic conditions at pHs of 1-5, the particle size was significantly smaller than that at pHs of 6-9; additionally, the absolute values of potential from ANSs prepared under acidic conditions were generally greater than that at $\mathrm{pHs}$ of 6-9; Furthermore, under acidic conditions, decreasing the $\mathrm{pH}$ led to a reduction of the particle size of ANSs with drug loading of $50 \%$, along with a reduction from $266 \mathrm{~nm}$ to $164 \mathrm{~nm}$. Obviously, the acidic conditions, in particular pHs of 1-4, facilitated the formation of ANSs. It has been reported that in acidic conditions the globular protein is unable to maintain its rigid structure, becomes expandable and hollow, and, consequently, has greater capability to adsorb other molecules [24,25]. Accordingly, the increased adsorption of hydrophobic drug into the protein could induce changes in the protein's structure and the microenvironment of intrinsic residuals. To prove our assumption, fluorescence and CD spectra were performed. As depicted in Figure 2C, significantly, the maximum fluorescence intensity at around $340 \mathrm{~nm}$ from $\mathrm{pHs}$ of 1-5 was greater than that of $\mathrm{pHs}$ of $6-9$. These results implied that the Trp residues of protein were embedded in a stronger hydrophobic condition and, in turn, demonstrated the improved adsorption of hydrophobic drug under acidic conditions. Additional examination of CD spectroscopy demonstrated that $\mathrm{pHs}$ of 1-4 induced red shift from around $220 \mathrm{~nm}-200 \mathrm{~nm}$ and $\mathrm{pHs}$ of 1 and 2 enabled increased negative minimum at approximately $200 \mathrm{~nm}$ compared with that of water 
(Figure 2D); however, pHs of 6-9 had little effect on the negative minimum (Figure 2E). The results indicated that acidic conditions could change the secondary and tertiary structure of the protein and that decreasing the $\mathrm{pH}$ from 4 to 1 allowed for more profound alteration. Collectively, we initially identified that the potential reason the acidic condition improved the drug loading and facilitated the formation of ANSs was due to the changes of the protein's structure.
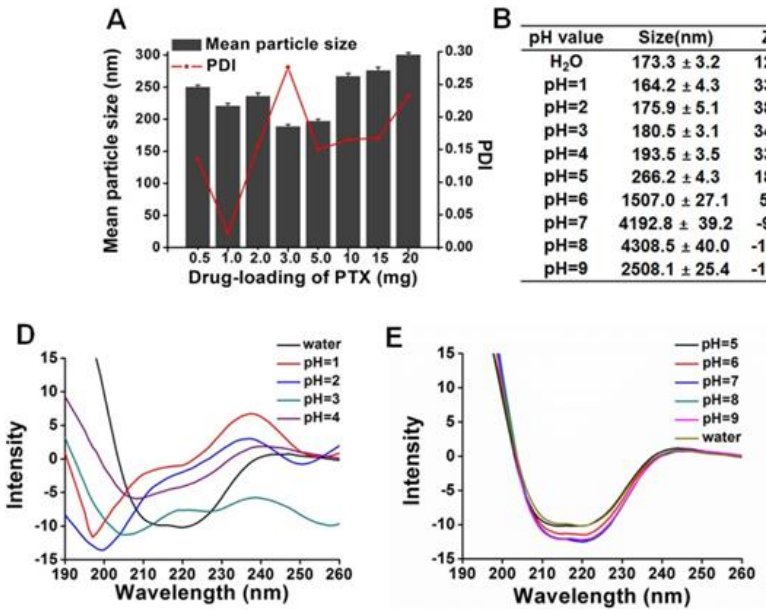
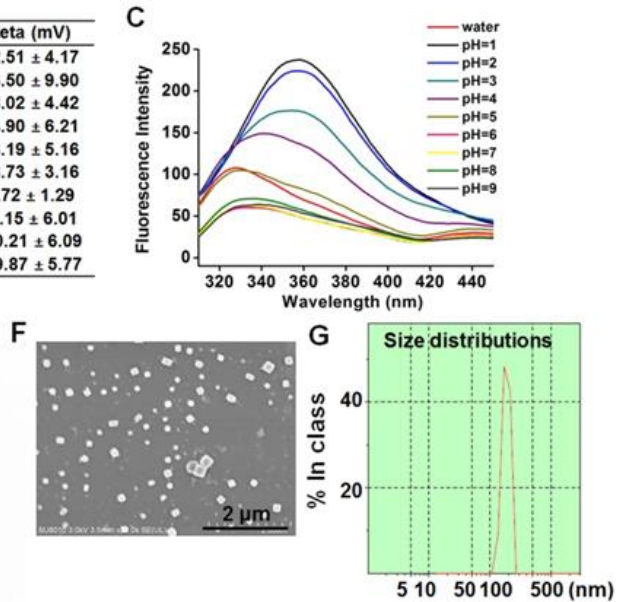

Figure 2. (A) The particle size with the drug loading of PTX from 0.5-20 mg. (B) Particle size and zeta potential of ANSs with the $\mathrm{pH}$ value ranging from 1-9. (C) The fluorescence emission spectrum of $\mathrm{Hb}$ with $\mathrm{pH}$ from 1-9. The far UV Circular Dichroism (CD) spectrum of $\mathrm{Hb}$ at $\mathrm{pH}(\mathrm{D})$ ranging from 1-4 or (E) ranging from 5-9. (F) The scanning electron microscopy (SEM) image and (G) size distribution of ANSs with $50 \%$ loading of PTX.

Overall, ANSs with drug loadings of 30\% and 50\% had a particle size less than $200 \mathrm{~nm}$; however, the latter had higher drug loading and was selected for further study. SEM examination revealed that the ANSs had a tetragonal structure with a size of 150-250 nm (Figure 2F), being in line with the DLS results (Figure 2G).

\subsection{Amorphous State and In Vitro Drug Release}

To study the drug state in ANSs, examinations of PXRD and DSC were performed. Pure PTX displayed characteristic crystal peaks at a $2 \theta$ angle of 5.0, 9.0, 10.0 and 12.0 [26], demonstrating high crystallinity (Figure 3A). Similar crystalline peaks were displayed in the physical mixture (PM). By contrast, no diffraction peaks of the drug in ANSs with $30 \%$ or $50 \%$ drug loading was observed, indicating an amorphous state. DSC examination presented endothermic peak of the drug at $200{ }^{\circ} \mathrm{C}$ in the samples of pure drug and PM, while this peak disappeared in ANSs (Figure 3B). Again, the DSC results indicated the drug dispersed as amorphous state in ANSs. 
A



B

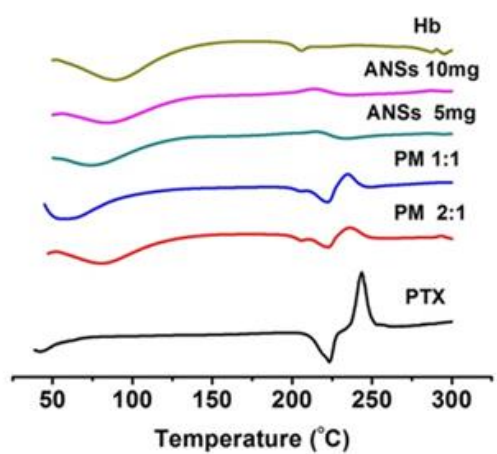

Figure 3. (A) Physical state of the drug in ANSs analyzed by PXRD and (B) differential scanning calorimetry (DSC). PM 1:1 and 2:1 indicate physical mixture (PM) of $\mathrm{Hb}$ /PTX at mass ratios of 1:1 and 2:1.

To further ascertain the amorphous state, test of in vitro drug release was performed. As shown in Figure 4, the ANSs exhibited significantly faster drug release even compared with the free drug formulation, Taxol. The amorphous drug possessed a higher energy state and had a higher saturation solubility and more rapid dissolution velocity [27]. Additionally, an increase in surface area due to the nanoscaled size of ANSs contributed to the faster release as well. Overall, these results confirmed the amorphous drug in ANSs.

A

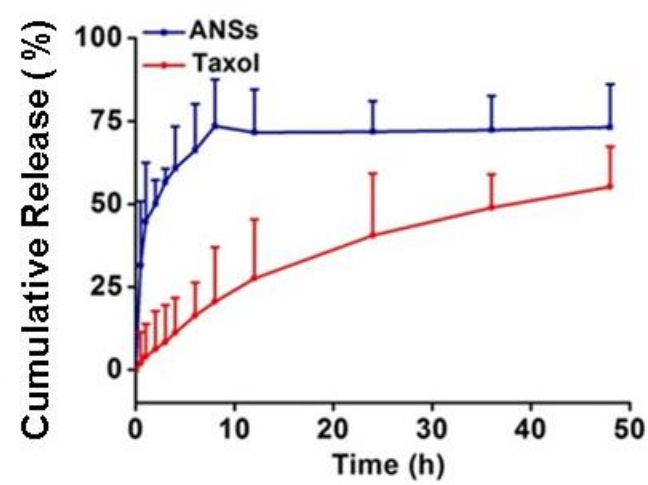

B

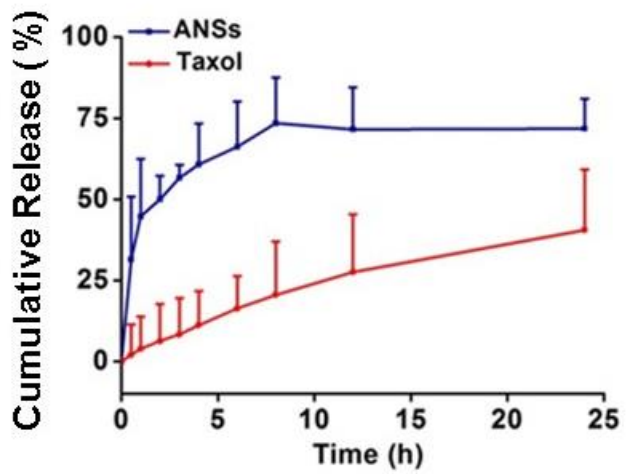

Figure 4. In vitro release profile of PTX from Taxol and ANSs in (A) a $48 \mathrm{~h}$ duration, and (B) in the first $24 \mathrm{~h}$ period $(n=5)$.

\subsection{Cellular Uptake and Cytotoxicity}

The uptake of ANSs of PTX in A549 cells was determined with PTX nanocrystals (LPNs) as a control. Significantly, the cells exhibited stronger green fluorescence from FITC-ANSs compared to that from FITC-LPNs after $4 \mathrm{~h}$ incubation at $37^{\circ} \mathrm{C}$ or $4{ }^{\circ} \mathrm{C}$ (Figure 5A). Quantified assay by FCM demonstrated that the uptake of these two nanoparticles was time-related in a $4 \mathrm{~h}$ period (Figure 5B). Importantly, the uptake of FITC-ANSs was higher than that of FITC-LPNs after $2 \mathrm{~h}$ incubation. The increased uptake was ascribed to the positively charged ANSs (Figure 2B) that improved the interplay between the nanoparticles and cell membrane. 

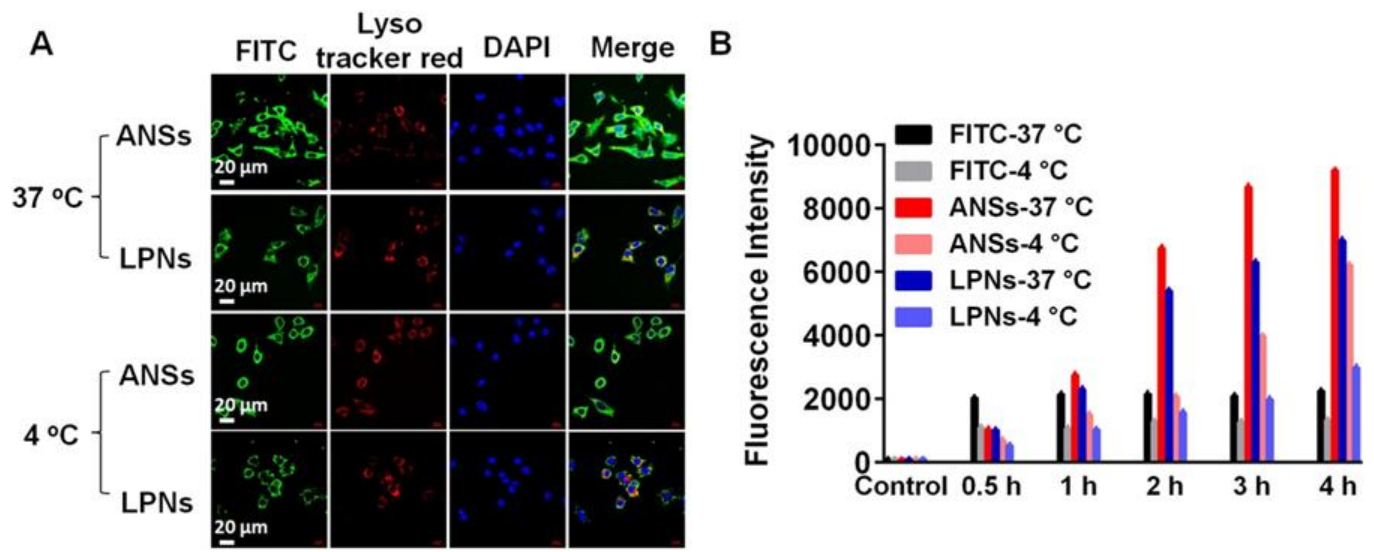

Figure 5. (A) Comparison of cellular uptake of FITC-labelled complexes of ANSs (FITC-ANSs) and FITC-labelled LPNs (FITC-LPNs) at $37{ }^{\circ} \mathrm{C}$ and $4{ }^{\circ} \mathrm{C}$ in A549 cells after $4 \mathrm{~h}$ incubation at a FITC concentration of $2.5 \mu \mathrm{g} / \mathrm{mL}$. (B) Quantification of cellular uptake assayed by flow cytometry $(n=5)$.

To determine the internalization pathway, A549 cells were pretreated with various endocytic inhibitors and then incubated with FITC-ANSs for $4 \mathrm{~h}$ at $37^{\circ} \mathrm{C}$. Inhibitors included Cy-D, nystatin, CPZ, $\mathrm{NOD}, \mathrm{M}-\mathrm{CD}, \mathrm{MON}$, and $\mathrm{NaN}_{3}+\mathrm{DG}$ were involved in the study, which inhibits macropinocytosis, caveolae-mediated internalization, clathrin-mediated uptake, microtubule-related internalization, lysosome-related endocytosis, cholesterol-dependent process and energy-dependent mechanisms, respectively [28,29]. As shown in Figure 6A, the uptake of ANSs was reduced by approximately $30 \%$ by four inhibitors-CPZ, NOD, $\mathrm{MON}$ and $\mathrm{NaN}_{3}+\mathrm{DG}$ - compared with the control group pretreated with saline. CLSM observation confirmed the results (Figure 6B). These results implied that the uptake of the nanoparticles was controlled by multi-pathway, including clathrin-mediated endocytosis, microtubule-related internalization and cholesterol-dependent process with energy-dependence.
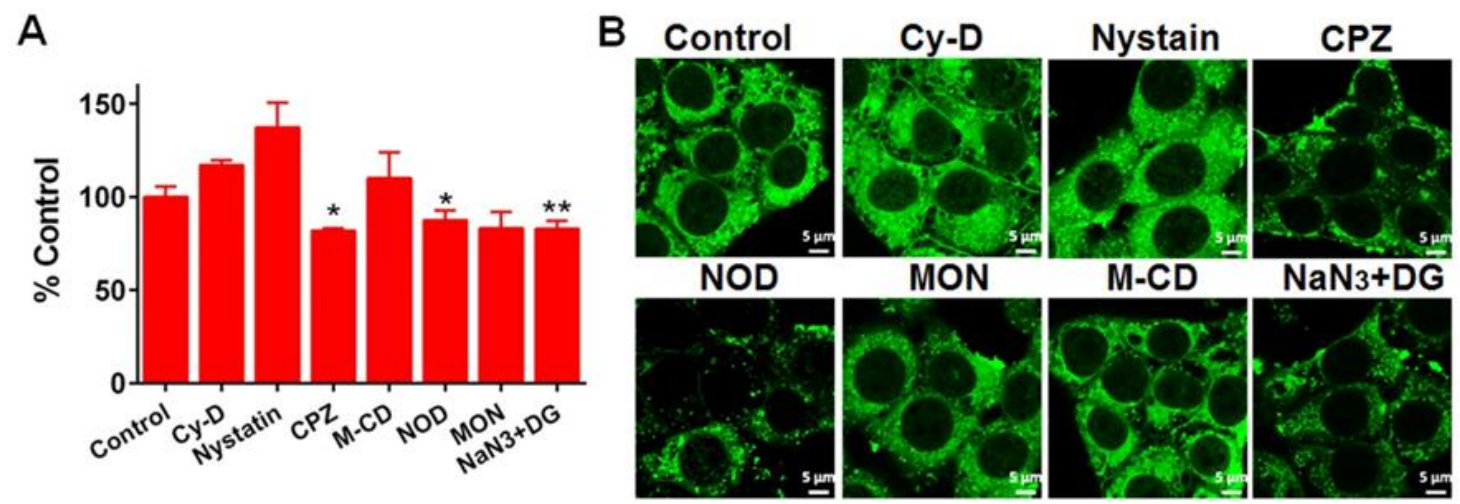

Figure 6. Endocytosis mechanism of FITC-ANSs in A549 cells. (A) Quantification uptake pretreated with cellular uptake inhibitors by flow cytometry $\left(n=5,{ }^{*} p<0.05\right.$ and $\left.{ }^{* *} p<0.01\right)$; (B) confocal laser scanning microscope (CLSM) image. The examination was performed after $4 \mathrm{~h}$ incubation at an FITC concentration of $2.5 \mu \mathrm{g} / \mathrm{mL}$.

The cytotoxicity against different nanoparticles was evaluated by an MTT assay. The proteins, $\mathrm{Hb}$ and $\beta-\mathrm{LG}$, had negative effect on the cell viability at a protein concentration of less than $1000 \mu \mathrm{g} / \mathrm{mL}$ (Figure 7A,B), demonstrating their excellent biocompatibility. The viability of ANSs after $48 \mathrm{~h}$ incubation was less than that of LPNs at PTX concentrations $\geq 0.5 \mu \mathrm{g} / \mathrm{mL}$ and $10 \mu \mathrm{g} / \mathrm{mL}$ for $4 \mathrm{~T} 1$ and A549 cells, respectively (Figure 7C,D). An apoptotic test displayed that ANSs were able to induce the apoptosis of $4 \mathrm{~T} 1$ cells with higher efficiency compared to LPNs (Figure 7E), increasing the apoptosis 
rate by $10 \%$. Additionally, compared with Taxol, both of the two nanoparticles killed the cancer cells more significantly, along with approximately $10 \%$ increase in apoptosis rate, owing to their enhanced intracellular delivery of the drug. These results indicate that ANSs possess improved cytotoxicity over LPNs.

A

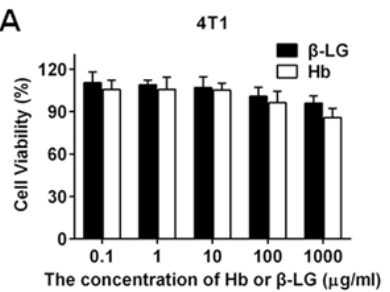

C

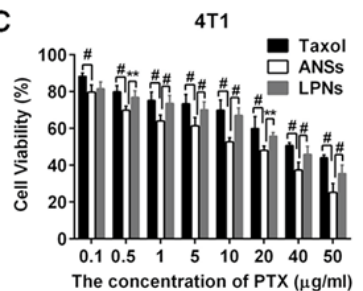

B
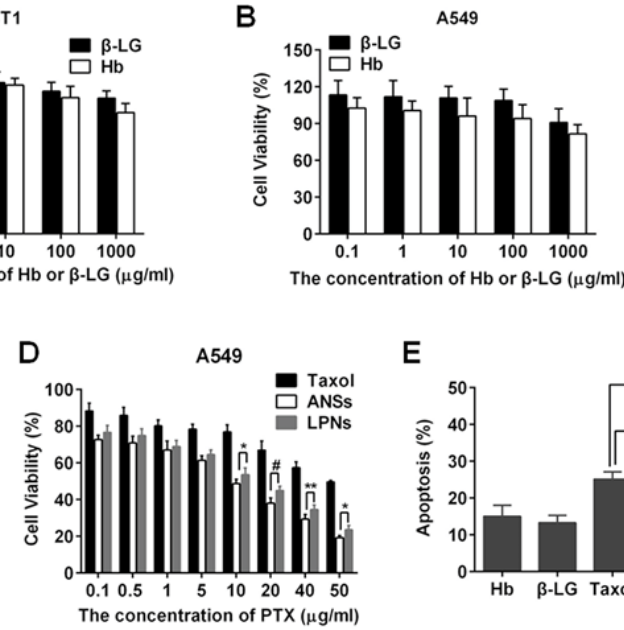

$E$

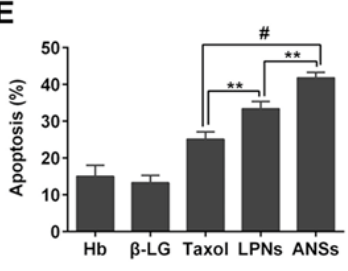

Figure 7. Cytotoxicity of $\mathrm{Hb}$ and $\beta$-LG from 0.1 to $1000 \mu \mathrm{g} / \mathrm{mL}$ in (A) $4 \mathrm{~T} 1$ and (B) A549 cells. Comparison of the cytotoxicity between ANSs and LPNs with the dose of PTX from 0.1 to $50 \mu \mathrm{g} / \mathrm{mL}$ in (C) $4 \mathrm{~T} 1$ and (D) A549 cells. The incubation time was $48 \mathrm{~h}$. (E) Apoptosis rate determined by flow cytometry after $48 \mathrm{~h}$ incubation at a PTX concentration of $10 \mu \mathrm{g} / \mathrm{mL}$ at $37^{\circ} \mathrm{C}\left(n=3,{ }^{* *} p<0.01\right.$ and $\left.{ }^{*} p<0.001\right)$.

Releasing a considerable amount of the drug in-cell in a short period would help saturate the efflux pump and, consequently, decline the efflux of the drug and compromise the drug resistance [30]. The drug state in ANSs and LPNs was different, with the former having an amorphous state and the latter possessing a crystalline form. As displayed in Figure 4, ANSs improved the drug release significantly even compared with the Taxol; therefore, we speculated that ANSs had the potential to release their drug into cells rapidly. In contrast, it takes several hours to dissolve the intracellular nanocrystals $[10,11]$. Thus, we ascertained that completed drug release from ANSs would occur within a short amount of time. Indeed, ANSs caused a 10\% increase in apoptosis rate compared to LPNs. Therefore, the drug state in nanosuspensions influences its pharmacological properties and, importantly, having amorphous form could enhance the activity of the drug.

\section{Conclusions}

In this study, using $\mathrm{Hb}$ as a carrier, <300 nm ANSs of PTX aggregated from drug-protein complexes were developed. The affinity study demonstrated robust interaction between the drug and protein. The ANSs were uptaken by cells well, and exhibited improved cytotoxicity compared with the crystalline nanosuspensions. Overall, a novel amorphous nanosuspension formulation of PTX aggregated from drug- $\mathrm{Hb}$ complex was developed and had the robust ability to kill cancer cells.

Author Contributions: X.X., X.P. and C.Q. completed all the experiments. W.H. and X.X. processed the data and wrote the manuscript. W.H. and L.Y. conceived and designed the experiments and reviewed the collection of results and data interpretation. All authors reviewed and approved the final version of the manuscript.

Funding: This research was funded by the National Natural Science Foundation of China (Nos. 81673377 and 81473152), the Ministry of Science and Technology of China (2017ZX09101001), and the Fostering Plan of University Scientific and Technological Innovation Team and Key Members of the Outstanding Young Teacher of Jiangsu Qing Lan Project (2016).

Conflicts of Interest: The authors declare that there are no conflicts of interest. 


\section{References}

1. Miriyala, N.; Ouyang, D.; Perrie, Y.; Lowry, D.; Kirby, D.J. Activated carbon as a carrier for amorphous drug delivery: Effect of drug characteristics and carrier wettability. Eur. J. Pharm. Biopharm. 2017, 115, 197-205. [CrossRef] [PubMed]

2. Yang, S.; Gao, H. Nanoparticles for modulating tumor microenvironment to improve drug delivery and tumor therapy. Pharm. Res. 2017, 126, 97-108. [CrossRef] [PubMed]

3. Gao, H. Shaping tumor microenvironment for improving nanoparticle delivery. Curr. Drug Metab. 2016, 17, 731-736. [CrossRef] [PubMed]

4. Wang, Y.; Zheng, Y.; Zhang, L.; Wang, Q.; Zhang, D. Stability of nanosuspensions in drug delivery. J. Control. Release 2013, 172, 1126-1141. [CrossRef] [PubMed]

5. Rabinow, B.E. Nanosuspensions in drug delivery. Nat. Rev. Drug Dis. 2004, 3, 785-796. [CrossRef] [PubMed]

6. Fuhrmann, K.; Gauthier, M.A.; Leroux, J.C. Targeting of injectable drug nanocrystals. Mol. Pharm. 2014, 11, 1762-1771. [CrossRef] [PubMed]

7. Matteucci, M.E.; Brettmann, B.K.; Rogers, T.L.; Elder, E.J.; Williams, R.O.; Johnston, K.P. Design of potent amorphous drug nanoparticles for rapid generation of highly supersaturated media. Mol. Pharm. 2007, 4, 782-793. [CrossRef] [PubMed]

8. Cheow, W.S.; Kiew, T.Y.; Yang, Y.; Hadinoto, K. Amorphization strategy affects the stability and supersaturation profile of amorphous drug nanoparticles. Mol. Pharm. 2014, 11, 1611-1620. [CrossRef] [PubMed]

9. Yonashiro, H.; Higashi, K.; Morikawa, C.; Ueda, K.; Itoh, T.; Ito, M.; Masu, H.; Noguchi, S.; Moribe, K. Morphological and physicochemical evaluation of two distinct glibenclamide/hypromellose amorphous nanoparticles prepared by the antisolvent method. Mol. Pharm. 2018, 15, 1587-1597. [CrossRef] [PubMed]

10. Gao, W.; Lee, D.; Meng, Z.; Li, T. Exploring intracellular fate of drug nanocrystals with crystal-integrated and environment-sensitive fluorophores. J. Control. Release 2017, 267, 214-222. [CrossRef] [PubMed]

11. Lu, Y.; Qi, J.; Dong, X.; Zhao, W.; Wu, W. The in vivo fate of nanocrystals. Drug Dis. Today 2017, $22,744-750$. [CrossRef] [PubMed]

12. He, W.; Wang, Y.; Lv, Y.; Xiao, Q.; Ye, L.; Cai, B.; Qin, C.; Han, X.; Cai, T.; Yin, L. Denatured protein stabilized drug nanoparticles: Tunable drug state and penetration across the intestinal barrier. J. Mater. Chem. B 2017, 5 , 1081-1097. [CrossRef]

13. Zhang, L.; Xiao, Q.; Wang, Y.; Zhang, C.; He, W.; Yin, L. Denatured protein-coated docetaxel nanoparticles: Alterable drug state and cytosolic delivery. Int. J. Pharm. 2017, 523, 1-14. [CrossRef] [PubMed]

14. Jia, Y.; Duan, L.; Li, J. Hemoglobin-based nanoarchitectonic assemblies as oxygen carriers. Adv. Mater. 2016, 28, 1312-1318. [CrossRef] [PubMed]

15. Rowinsky, E.K.; Onetto, N.; Canetta, R.M.; Arbuck, S.G. Taxol: The first of the taxanes, an important new class of antitumor agents. Semin. Oncol. 1992, 19, 646-662. [PubMed]

16. Koudelka, Š.; Turánek, J. Liposomal paclitaxel formulations. J. Control. Release 2012, 163, 322-334. [CrossRef] [PubMed]

17. Xin, X.; Pei, X.; Yang, X.; Lv, Y.; Zhang, L.; He, W.; Yin, L. Rod-shaped active drug particles enable efficient and safe gene delivery. Adv. Sci. 2017, 4, 1700324. [CrossRef] [PubMed]

18. He, W.; Xin, X.; Li, Y.; Han, X.; Qin, C.; Yin, L. Rod-shaped drug particles for cancer therapy: The importance of particle size and participation of caveolae pathway. Part. Part. Syst. Charact. 2017, 34, 1600371. [CrossRef]

19. Liang, L.; Tajmir-Riahi, H.A.; Subirade, M. Interaction of beta-lactoglobulin with resveratrol and its biological implications. Biomacromolecules 2008, 9, 50-56. [CrossRef] [PubMed]

20. Zhang, J.; Field, C.J.; Vine, D.; Chen, L. Intestinal uptake and transport of vitamin b12-loaded soy protein nanoparticles. Pharm. Res. 2015, 32, 1288-1303. [CrossRef] [PubMed]

21. Zhang, J.; Tian, Z.; Liang, L.; Subirade, M.; Chen, L. Binding interactions of beta-conglycinin and glycinin with vitamin b12. J. Phys. Chem. B 2013, 117, 14018-14028. [CrossRef] [PubMed]

22. Chakraborti, S.; Joshi, P.; Chakravarty, D.; Shanker, V.; Ansari, Z.A.; Singh, S.P.; Chakrabarti, P. Interaction of polyethyleneimine-functionalized $\mathrm{ZnO}$ nanoparticles with bovine serum albumin. Langmuir 2012, 28, 11142-11152. [CrossRef] [PubMed] 
23. Diarrassouba, F.; Liang, L.; Remondetto, G.; Subirade, M. Nanocomplex formation between riboflavin and $\beta$-lactoglobulin: Spectroscopic investigation and biological characterization. Food Res. Int. 2013, 52, 557-567. [CrossRef]

24. Tanford, C.; Buzzell, J.G.; Rands, D.G.; Swanson, S.A. The reversible expansion of bovine serum albumin in acid solutions1. J. Am. Chem. Soc. 1955, 77, 6421-6428. [CrossRef]

25. Zhou, L.; Yang, T.; Wang, J.; Wang, Q.; Lv, X.; Ke, H.; Guo, Z.; Shen, J.; Wang, Y.; Xing, C.; et al. Size-tunable $\mathrm{Gd}_{2} \mathrm{O}_{3} @$ albumin nanoparticles conjugating chlorin e6 for magnetic resonance imaging-guided photo-induced therapy. Theranostics 2017, 7, 764-774. [CrossRef] [PubMed]

26. He, W.; Lv, Y.; Zhao, Y.; Xu, C.; Jin, Z.; Qin, C.; Yin, L. Core-shell structured gel-nanocarriers for sustained drug release and enhanced antitumor effect. Int. J. Pharm. 2015, 484, 163-171. [CrossRef] [PubMed]

27. Junghanns, J.U.; Müller, R.H. Nanocrystal technology, drug delivery and clinical applications. Int. J. Nanomed. 2008, 3, 295-309.

28. Li, Y.; Wu, Z.; He, W.; Qin, C.; Yao, J.; Zhou, J.; Yin, L. Globular protein-coated paclitaxel nanosuspensions: Interaction mechanism, direct cytosolic delivery, and significant improvement in pharmacokinetics. Mol. Pharm. 2015, 12, 1485-1500. [CrossRef] [PubMed]

29. Liu, C.; Zhen, X.; Wang, X.; Wu, W.; Jiang, X. Cellular entry fashion of hollow milk protein spheres. Soft Matter 2011, 7, 11526-11534. [CrossRef]

30. Mohammad, I.S.; He, W.; Yin, L. Smart paclitaxel-disulfiram nanococrystals for efficient MDR reversal and enhanced apoptosis. Pharm. Res. 2018, 35, 77. [CrossRef] [PubMed]

(C) 2018 by the authors. Licensee MDPI, Basel, Switzerland. This article is an open access article distributed under the terms and conditions of the Creative Commons Attribution (CC BY) license (http:/ / creativecommons.org/licenses/by/4.0/). 